\title{
REVIEW
}

\section{Glia and immune cell signaling in bipolar disorder: insights from neuropharmacology and molecular imaging to clinical application}

\author{
CC Watkins ${ }^{1}$, A Sawa ${ }^{1}$ and MG Pomper ${ }^{1,2}$
}

Bipolar disorder (BD) is a debilitating mental illness characterized by severe fluctuations in mood, sleep, energy and executive functioning. Pharmacological studies of selective serotonin reuptake inhibitors and the monoamine system have helped us to clinically understand bipolar depression. Mood stabilizers such as lithium and valproic acid, the first-line treatments for bipolar mania and depression, inhibit glycogen synthase kinase-3 beta (GSK-3 $\beta$ ) and regulate the Wnt pathway. Recent investigations suggest that microglia, the resident immune cells of the brain, provide a physiological link between the serotonin system and the GSK-3 $\beta /$ Wnt pathway through neuroinflammation. We review the pharmacological, translational and brain imaging studies that support a role for microglia in regulating neurotransmitter synthesis and immune cell activation. These investigations provide a model for microglia involvement in the pathophysiology and phenotype of BD that may translate into improved therapies.

Translational Psychiatry (2014) 4, e350; doi:10.1038/tp.2013.119; published online 21 January 2014

Keywords: bipolar disorder; GSK-3ß; inflammation; microglia; TSPO; Wnt

\section{INTRODUCTION}

Bipolar disorder (BD) is a pervasive, psychiatric illness that affects 5.7 million people in the United States. ${ }^{1}$ BD is characterized by fluctuating mood states, cognitive impairment and functional disability. Depressive episodes are the major contributing factor to the disability associated with bipolar illness, often first presenting in later adolescence and early adulthood. ${ }^{2}$ Because the impulsivity and grandiosity in mania may be misdiagnosed as a behavioral problem or attributed to another mental disorder, there is an estimated 10-year delay between onset of $\mathrm{BD}$ and accurate diagnosis. ${ }^{3}$ Therefore, early pharmacological management of BD is critical in order to avoid long-term disability and the increased health service utilization often associated with the illness. ${ }^{3,4}$

Although only marginally understood, the pathophysiology of BD has traditionally been attributed to deficits in monoamine neurotransmitters, with a focus on serotonin, based on the mechanism of action of antidepressants. In clinical practice, patients that fail to respond to an optimized regimen of mood stabilizers tend to respond to augmentation with selective serotonin reuptake inhibitors (SSRIs). ${ }^{5}$ Bipolar depression mistaken for major depressive disorder (MDD) and treated with SSRIs can cause a 'switch' effect where patients may become manic. ${ }^{6-8}$ Although the serotonin system in particular has been implicated in the pathophysiology of bipolar depression, a growing body of evidence is shifting from theories of simple deficits in serotonin to those based on effects secondary to abnormalities in neuronal plasticity. In this context, plasticity is defined as an experiencedependent change in synaptic strength, cell resilience and/or connectivity. ${ }^{7,9,10}$ Homeostasis, support and protection of neurons are maintained by glia cells (microglia and astrocytes) in the brain and peripheral nervous system. Although astrocytes are large stellate cells that provide biochemical support, microglia are specialized macrophages capable of phagocytosis in order to protect neurons in the central nervous system (CNS). Microglia appear to function as sensors and regulators of serotonin production through proinflammatory cytokines in the brain. One link between microglia and serotonin production may be inflammatory signaling in the kynurenine pathway (KYP), an alternate route of tryptophan metabolism that decreases serotonin neurotransmission (Figure 1). Changes in the cytokine environment and serotonin production mediated by microglia appear to lead to long-term changes in synaptic function and downstream effects of apoptosis, excitotoxicity, neurogenesis and neurotrophic production. ${ }^{11,12}$ Developmental, neuropathological and imaging data in basic science and clinical models of BD demonstrate that serotonin production and neuronal connectivity are dependent on immune cytokine pathways in the periphery and the brain. ${ }^{13-16}$

Mood stabilizers such as lithium (Li) and valproic acid (VPA) are the first-line pharmaceutical agents used in both the depressed and manic phases of $\mathrm{BD}^{17,18}$. Although the mechanism of action of $\mathrm{Li}$ and VPA are unclear, they both appear to reduce immune cell signaling through inactivation of the enzyme glycogen synthase kinase-3 beta (GSK-3 $\beta$ ) in the Wnt pathway. Li and VPA also inactivate other enzymes involved in inflammation, including cyclooxygenase 2 and aracadonic acid. ${ }^{19}$ Recent data suggest that the Wnt family of lipoglycoproteins signal microglia activation through pro-inflammatory cytokines and $\beta$-catenin signaling networks (Figure 2). ${ }^{20}$ Gene-expression profiling also reveals that Wnt-3A stimulation specifically increases the expression of proinflammatory immune response genes in microglia and exacerbates the release of interleukin (IL)- $6, \mathrm{IL}-12$ and tumor necrosis factor (TNF-a). ${ }^{20,21}$

\footnotetext{
${ }^{1}$ Department of Psychiatry and Behavioral Sciences, John Hopkins University School of Medicine, Baltimore, MD, USA and ${ }^{2}$ Division of Neuroradiology, Department of Radiology, Johns Hopkins University School of Medicine, Baltimore, MD, USA. Correspondence: Dr CC Watkins, Department of Psychiatry and Behavioral Sciences, Johns Hopkins University School of Medicine, 600 North Wolfe Street, Phipps 300, Baltimore, MD 21287-0005, USA. 


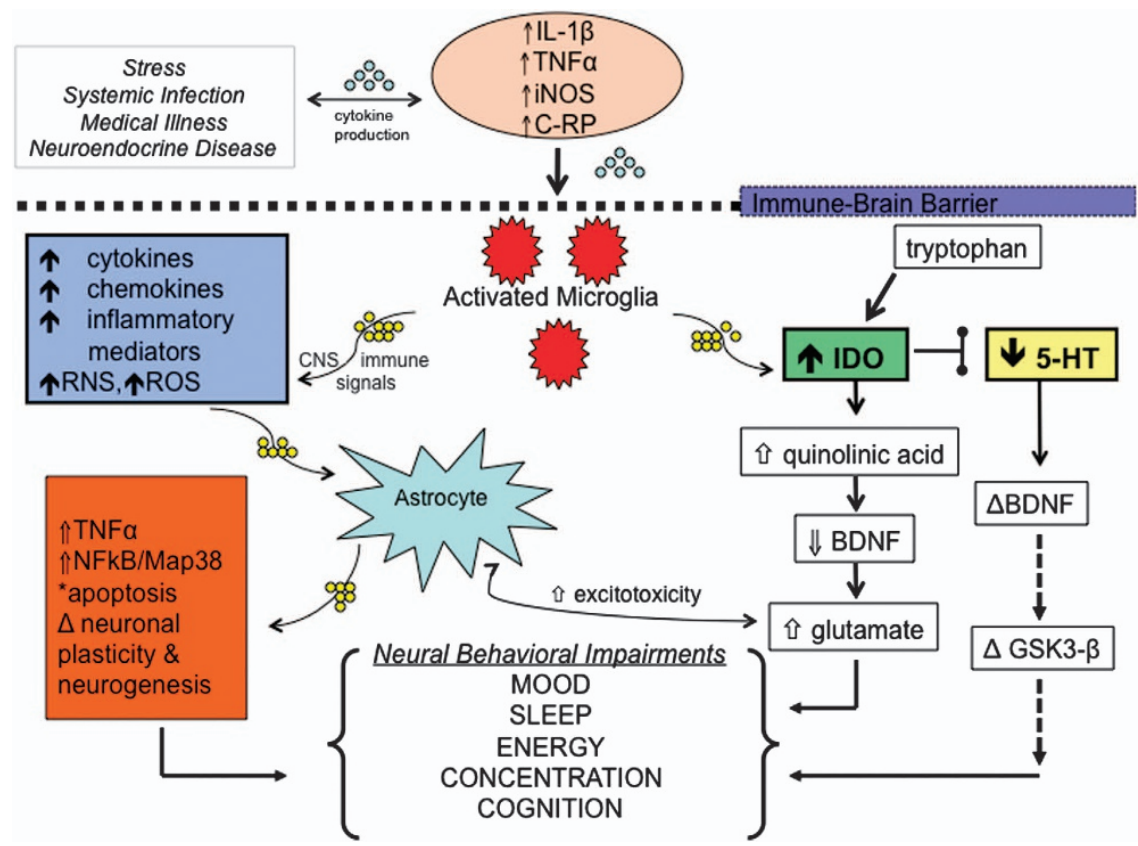

Figure 1. Proposed role of activated microglia in the modulation of inflammatory mediators, neurotransmitter synthesis and synaptic plasticity in bipolar disorder (BD). CRP, C-reactive protein; IDO, indoindoleamine 2,3-dioxygenase; 5-HT-serotonin; RNS, reactive nitrogen species; ROS, reactive oxygen species.

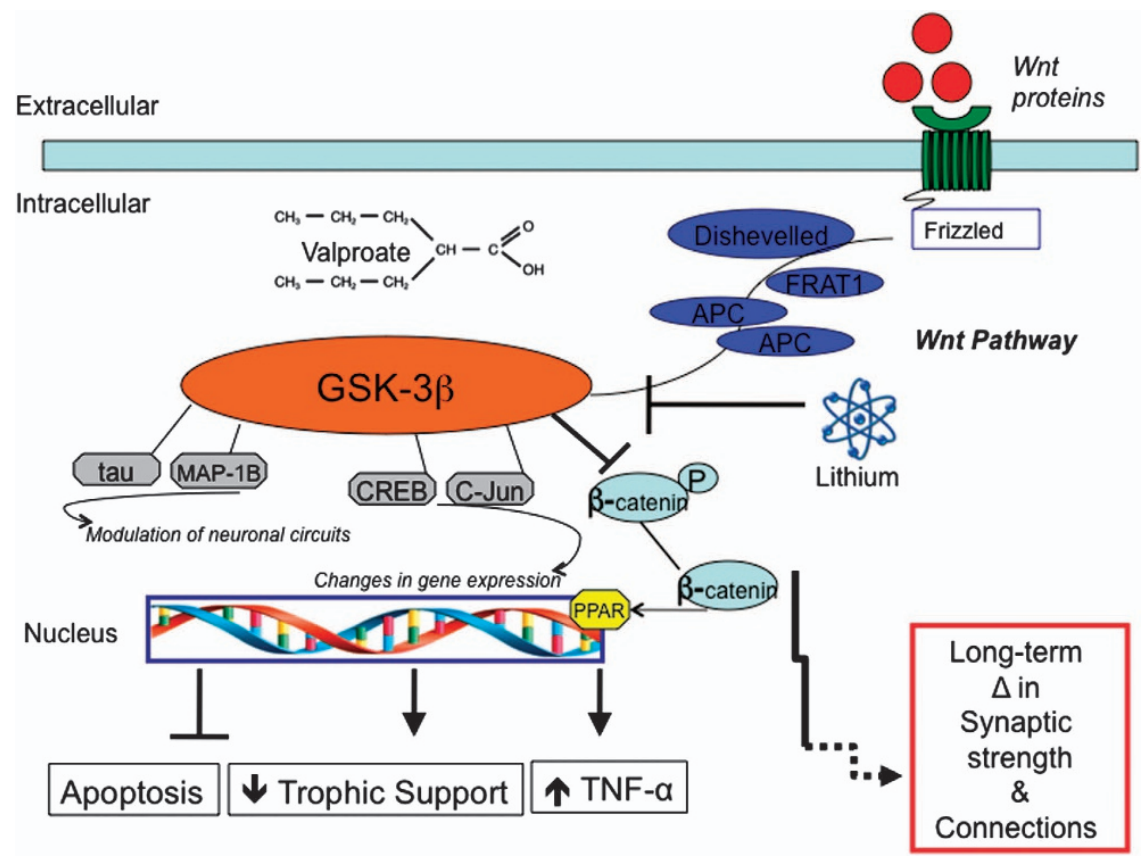

Figure 2. The Wnt/GSK- $3 \beta$ pathway.

Given the strength of the evidence for involvement of neuroinflammatory processes in integrating the serotonin system with the Wnt pathway, the focus of this article is to critically examine the role microglia have in BD. We will relate findings in these signaling pathways to pharmacological treatment and clinical systems, based on current data and translational models for investigating the pathology and physiology of BD.

\section{ANTIDEPRESSANTS, SEROTONIN AND THE KYP}

Serotonin and bipolar depression

Monoamines have been implicated in altered production, transport, storage, release, reuptake and degradation of neurotransmitters in BD. Excitatory $\mathrm{N}$-methyl-D-aspartate receptor and inhibitory gamma-aminobutyric acid amino acids, cholinergic 
and noradrenergic systems, corticotrophin releasing factor, thyrotropin releasing factor and other neurotransmitters and neuromodulators have been linked to the depressive phase of $\mathrm{BD}^{22}$ SSRIs, in the form of commonly prescribed antidepressant drugs, have hel ped to expand our knowledge of both unipolar depression (MDD) and BD and the mechanisms behind these disorders. Serotonin is involved in mood, sleep, appetite and energy level, all of which are altered in BD. The illicit drug 3,4,methylene-dioxy-methamphetamine (ecstasy) inhibits the reuptake of serotonin through the serotonin transporter (5-HTT). In a mood state that resembles BD, the transient elevation in serotonin activity generates feelings of elation, followed by depressive feelings related to depleted serotonin when the drug wears off.

Multiple animal studies suggest that serotonin signaling may be influenced by immune cytokine pathways in the brain and periphery through the KYP. ${ }^{11,12}$ Activated microglia in the KYP trigger an alternate route of tryptophan metabolism that ultimately reduces overall serotonin availability in the brain (Figure 1). Cytokines such as IL-2 and IL-6, released in the periphery from macrophages and interferon-gamma (IFN- $\gamma$ ) from activated microglia within the CNS, may provoke overstimulation of the KYP that effectively depletes CNS serotonin levels and alters trophic support from brain-derived neurotrophic factor (BDNF) and TNF-a. ${ }^{23-25}$ A systematic meta-analysis of cytokines in BD found evidence in support of peripheral inflammatory alterations. Significant increases were observed in several cytokines and receptors including soluble IL-2, IL-2 receptor, IL-4, IL-6 receptor and TNF-a. ${ }^{26}$ Signaling pathways involving pro-inflammatory cytokines have also been shown to increase the activity of the serotonin $5-\mathrm{HTT}$ in the brain, with inflammatory mediators in the KYP specifically connected to 5 -HTT in other organ systems. ${ }^{27,23,24}$

Genetic and postmortem studies demonstrate a higher propensity to develop affective illness in individuals with $5-\mathrm{HTT}$ regulatory site promoter region length polymorphisms (5-HTTLPR-s allele), and the associated cytokine-induced fatigue and depression symptoms were observed. ${ }^{28-31}$ Within the context of stressful events, there appear to be different allelic frequencies in BD compared with MDD, with no interaction with stress in conferring susceptibility in $\mathrm{BD} .{ }^{32-34}$ Although one rare, distinct $5-\mathrm{HTT}$ gene polymorphism was associated with greater chance of developing MDD but not $B D, 35$ data from a different series of studies using a genetic marker within the serotonin transporter found a 5-HTT-transporter polymorphism that occurs at a higher frequency in both MDD and BD. ${ }^{29,36,37}$

\section{Serotonin signaling through the KYP}

The KYP, activated by peripheral cytokines and mediated by microglia, is an increasingly attractive potential modulator of serotonin and BDNF. Serotonin and BDNF may also be connected through pro-inflammatory cytokines. Research focused at the interface between inflammatory cascades, neuroplasticity and depression have demonstrated that once peripheral cytokines gain access to the brain, they influence production, release and reuptake of serotonin, as well as norepinephrine and dopamine. ${ }^{12}$ In $\mathrm{BD}$ a decreased plasma ratio of tryptophan, the precursor to serotonin, to other large, neutral amino acids was demonstrated in acute mania. ${ }^{27,38}$ Those serotonin deficits in the manic phase of $\mathrm{BD}$ form the basis of an interesting hypothesis that overstimulation of the enzyme indoleamine 2,3-dioxygenase (IDO) by peripheral and central inflammatory mediators activates the consumption of tryptophan in the KYP (Figure 1) and leads to serotonin depletion. ${ }^{27,24,39,40}$ That pathway represents an alternative metabolic route for tryptophan. ${ }^{23,24,27,38}$ Activated microglia in the brain promote expression of cytokines that leads to increased IDO activity and CNS tryptophan depletion with a concurrent increase in brain quinolinic acid, a metabolite produced distally within the KYP. Another enzyme, tryptophan 2,3-dioxygenase, further metabolizes tryptophan in the periphery along the KYP. ${ }^{39}$ Because brain tryptophan levels depend on plasma levels, brain serotonin will be compromised by the systemic activity of these two enzymes. Overproduction of quinolinic acid, an excitotoxin, can further decrease BDNF, activate pro-apoptotic cascades by TNF-a and increase glutamate and N-methyl-D-aspartate receptor-activated excitotoxicity. ${ }^{23,39,41}$ Interestingly, brain imaging studies demonstrate a selective increase in glutamate in the occipital cortex during both acute exacerbation and remission of depression. ${ }^{42,43}$ We propose that a portion of the neuropsychiatric findings in both depression and mania may rely on that mechanism. Furthermore, activation of that pathway may lead to changes in synaptic resilience, connectivity of serotonergic neurons and/or programmed cell death. Some propose that the balance between production of quinolinic acid versus kynurenic acid may be more important than serotonin depletion in mediating symptoms in BD. Translational methods to study activated microglia and serotonin transmission, specifically the integrity of the presynaptic 5-HTT sites, may lend insight into the pathogenesis of BD-related symptoms.

Given that antidepressant treatments enhance monoamine function, to date translational research has focused on the serotonin (5-HT) system in unipolar depression with bipolar depression used as a comparison. ${ }^{32,44-46}$ However, results related to the serotonin transporter in BD have conflicted at times, due in part to the heterogeneity of the populations studied, the radiopharmaceuticals used, the active mood state of the patient and other methodological differences. ${ }^{32,45}$ Recent advances in radiotracer development and high-resolution molecular imaging of the brain provide an opportunity to evaluate the serotonin system, as well as innovative pathways involved in neuronal plasticity and neuroinflammation in BD.

\section{MOOD STABILIZERS, LI AND VPA AND THE WNT PATHWAY}

Mood stabilizers are linked to pro-inflammatory cytokine production

Mood stabilizers, the primary pharmacological treatments for BD, have been shown to affect neuroinflammatory pathways. ${ }^{18}$ Cell culture, animal models and clinical studies examining haloperidol, lamotrigine, carbamazepine, $\mathrm{Li}$ and VPA show changes in arachidonic acid, cytokines and other markers of inflammation in the presence of these medications. ${ }^{19,47-49}$ However, some of these studies have been contradictory because of the variability in the cell types studied, diagnosis of the subjects included (bipolar I, bipolar II and/or euthymic) and other medications taken during the study. Many of the studies include pretreatment scenarios with non-physiological dosages of the mood stabilizers, which can also skew the interpretation of the results. ${ }^{18}$ However, the trend is that $\mathrm{Li}$ and VPA, in particular, dampen the pro-inflammatory response in $\mathrm{BD}$ and may stimulate inflammatory markers in euthymic patients. ${ }^{47}$

Both Li and VPA appear to affect inflammatory pathways by downregulating markers of T-cell activation, IL- 2 and IFN- $\gamma$ and by reducing lipopolysaccharide (LPS)-induced dopaminergic neurotoxicity by inhibiting microglial over-activation. ${ }^{19,50}$ In a recent study of the effects of Li on LPS-induced inflammation on rat primary glia cells, Li decreased expression of cyclooxygenase 2 and iNOS. $^{51} \mathrm{Li}$ also decreased secretion of TNF- $\alpha$, IL1- $\beta$ and PGE(2), although only in the presence of supra-therapeutic dosages of $\mathrm{Li}$. In monocytes from healthy control subjects, Li increased IL-1 in a dose dependent manner and decreased levels of LPS, with no effect on IL-6. ${ }^{52}$ In contrast, another study in euthymic bipolar patients compared to healthy controls showed lower levels of IL-2, IL-6, IL-10 and IFN- $\gamma$ in the bipolar group only. ${ }^{53}$ The VPA pretreatment of glia cells is also suggested to reduce LPS-induced pro-inflammatory responses by limiting microglial activation 
through the enzyme histone deacetylase, thus decreasing dopamine-related neurotoxicity. ${ }^{50}$

$\mathrm{Li}$ and VPA also upregulate the expression of the neurotrophic factors BDNF and glial cell line-derived neurotrophic factor from astrocytes that promote cell survival, differentiation and growth. ${ }^{40,54-57}$ Another group demonstrated that monocytes of a large proportion of bipolar patients and offspring of bipolar parents showed an inflammatory gene expression signature. ${ }^{12,58}$ Those treated with Li and VPA appear to have a downregulated expression of a series of inflammatory genes. This body of literature supports investigating biomarkers for inflammatory mediators as a logical next step to identify both manic and depressed states in patients. In addition to gaining insight into the pathophysiology of $\mathrm{BD}$, information obtained from additional investigations may eventually help with therapeutic monitoring.

\section{The Wnt/GSK-3 $\beta$ pathway is a target for mood stabilizers}

A growing body of literature suggests that Li and VPA also target GSK-3 $\beta$ in the Wnt signaling pathway. The Wnt pathway is a highly conserved signaling cascade that is critical for synaptic plasticity, circadian rhythms and cell survival ${ }^{59}$ (Figure 2). GSK-3 $\beta$ is the principal enzyme in the Wnt pathway and appears to share a common link between proteins involved in immune response and clinical characteristics of $\mathrm{BD}$, as well as schizophrenia and unipolar depression. ${ }^{60-62}$ Therefore, inflammatory cytokines, working through this signal transduction mechanism, may be a potential target for therapeutic intervention in BD. Medication induced and transgenic mouse models suggest that $L i$ and VPA directly inhibit GSK-3 $\beta$ by upregulating expression of BDNF and glial cell linederived neurotrophic factor from astrocytes and microglia that promote cell survival, differentiation and growth. ${ }^{61,63,64}$ In vitro studies using neuronal cell lines also demonstrate that Li and VPA inhibit GSK-3 $\beta$ that leads to an accumulation of $\beta$-catenin. $\beta$-catenin, as a transcription factor, stimulates other neurotrophic factors and attenuates the activation of microglia. ${ }^{12,47,65}$ Therefore, the Wnt pathway is important for mood stabilizer activity and inflammatory signaling.

\section{Genetic studies of Wht proteins in inflammation and BD}

An emerging body of literature supports the hypothesis that genetic aberrations or polymorphisms in the Wnt signaling pathway may be involved in $\mathrm{BD} .^{8}$ In studies of monozygotic twins discordant for BD, 292 genes were found to be differentially expressed in $\mathrm{BD}$, with eight genes in the Wnt signaling pathway. ${ }^{66}$ Family-based association studies of 554 offspring with BD and their parents from 317 families found evidence for an association of BD susceptibility within the peroxisome proliferator-activated receptor $(P P A R)$ gene family in the Wnt signaling pathway. ${ }^{55,67}$ Specifically, one group observed an association with a singlenucleotide polymorphism repeat that was within a singlehaplotype block that spanned exons 3-7 of the gene on chromosome $6 \mathrm{p}$. BD patients with a higher degree of functional impairment and carrying an allele in Wnt-2B or Wnt-7A were more strongly associated with this single-nucleotide polymorphism. ${ }^{60}$ Chromosome $6 \mathrm{p}$ ha $\mathrm{s}$ not been implicated directly by linkage studies of $\mathrm{BD}$, although this region contains several interesting candidate genes that have been associated with both schizophrenia and psychotic BD. ${ }^{68-71}$

Inflammation, cell proliferation and peroxisomal functioning are modulated by the PPAR family of nuclear hormone receptors. ${ }^{72}$ However, members of the PPAR gene family have not been widely investigated in association with either bipolar depression, bipolar mania or psychotic disorders. Murine brain, skin and adipose tissue have significant gene expression of PPARD, with higher expression in the hippocampus, hypothalamus, entorhinal cortex, as well as within the corpus callosum and neostriatum. ${ }^{72,73}$ In rat models of neurodegeneration and ischemia, agonists of PPARD were neuroprotective. ${ }^{74}$ Several studies utilizing the Global Assessment of Functioning Scale, which captures both socialoccupational and interpersonal functioning, identified unemployment and functional impairment as the most highly familial features of BD among 40 variables tested. ${ }^{67,75}$ The association of $P P A R D$ gene with poor functioning is consistent with a potential role for Wnt dysfunction in moderate to severe BD. Taken together, these findings suggest that Wnt polymorphisms may confer vulnerability for developing $\mathrm{BD}$, and may act through inflammatory cascades to regulate trophic support to brain structures. Future studies that examine why BD symptoms cluster in families with Wnt gene polymorphisms and how this relates to serotonin signaling will enhance our understanding of the Wnt cascade in BD.

\section{MICROGLIA: THE KEY CELLS WHERE ACTIONS OF ANTIDEPRESSANTS AND MOOD STABILIZERS CONVERGE}

Microglia and immune signaling

Based on pharmacological evidence, microglia appear to have a functional role in serotonin neurotransmitter signaling through inflammatory mechanisms that ultimately affect the Wnt/GSK-3ß pathway and mood in $\mathrm{BD} .^{76}$ Glial cells have become increasingly important in understanding neuroplasticity and cellular resilience mechanisms. Astrocytes and microglia are subtypes of glial cells in the CNS. Microglia, as the resident macrophages of the brain, adapt rapidly and respond to changes in the CNS environment by regulating cytokine production and neuronal plasticity and neurotransmitter synthesis. Microglia are considered 'activated' after interacting with macrophages and undergo a morphological change. Activated microglia proliferate, express the 18-kDa translocator protein (TSPO) and release cytokines and other signal systems. ${ }^{76}$ Postmortem studies in BD suggest a decreased number and size of microglia. $47,82,84,108$ The deficit in density and overall number of glia were most notable in the prefrontal cortex and anterior cingulate cortex of participants with mood disorders. ${ }^{82,84,108}$ Collectively, this reduction in microglial growth argues for a mood disorder-specific glial pathology where decreased proliferation occurs before $\mathrm{BD}$ or as a result of a protracted course of degeneration where extensive gliosis has not yet been processed. Bipolar patients are proposed to have a higher inflammatory load of circulating monocytes at the transcriptome level involving various inflammatory transcripts, regulated by microglia and related to the Wnt signaling pathway. ${ }^{13}$ However, little is known about the role of activated microglia in BD in manic versus depressed mood episodes. Given that microglia help regulate cytokine production combined with the clinical evidence in the literature and our preliminary studies, there is increased support for investigating activated microglia and inflammatory cytokines as potential biomarkers for predicting disease exacerbation in both the manic and depressed states of the illness. ${ }^{12,26,47,77}$ Therefore, activated microglia may be a potential biomarker for mood states and a measure of pharmacological response in BD therapy.

\section{Serotonin signaling promotes inflammation through glial} signaling

Multiple SSRIs have been proposed to have an effect on microglia with both pro-and anti-inflammatory properties reported. ${ }^{78}$ The disparate findings of decreased TNF-a production, ${ }^{79}$ increased $^{80}$ and no effect ${ }^{81}$ on serotonin production may be because of the differences in experimental approach. One group recently demonstrated that at dosages consistent with pharmacological treatment, fluoxetine, sertraline, paroxetine and fluvoxamine significantly increased LPS-induced production of TNF-a. ${ }^{78}$ They also found that exposure over $24-\mathrm{h}$ and concentrations $<5 \mathrm{M}$ of antidepressants actually created a pro-inflammatory environment. At the molecular level, serotonin production is also modulated by 
microglia. As mentioned above, activated microglia promote expression of inflammatory cytokines that stimulate IDO activity and deplete CNS tryptophan. Activated microglia signaling cascades, because of enzyme activation in the KYP, ultimately lead to lower levels of serotonin and alterations in 5-HTT availability (Figure 1). ${ }^{41,82-84}$ Further tryptophan metabolism leads to overproduction of excitotoxins and additional cytokine activation, ultimately resulting in glutamate and $\mathrm{N}$-methyl-D-aspartate receptor excitotoxicity. Interestingly, brain imaging studies demonstrate a selective increase in glutamate in the occipital cortex during both acute exacerbation and remission of depression. ${ }^{41,85}$ We hypothesize, as have others, that a portion of the neuropsychiatric findings in both depression and mania may rely on microglia acting through KYP mechanisms.

Wnt proteins interact with microglia to promote inflammation The Wnt pathway is of interest in $\mathrm{BD}$ and molecular imaging investigations (Figure 2). We reviewed the role of Wnt-glial interactions in the section 'The Wnt/ GSK-3 $\beta$ pathway as a target for mood stabilizers', in our discussion, and their possible involvement in mood disorder. Although some argue that lack of sufficient clinical and postmortem data to support Wnt alterations in any mood disorder, ${ }^{86}$ pharmacological, neurodevelopmental and behavioral data point to the possibility of involvement of the Wnt pathway through glial-neuronal signaling. A recent series of studies provide strong evidence that Wnt-3A and Wnt-5A proteins act directly on $\beta$-catenin and drive a pro-inflammatory transformation of microglial cells. ${ }^{20,21,87}$ The Wnt family of lipoglycoproteins appear to direct response genes in microglia and generate de novo IL-6, IL-12 and TNF-a. Future clinical studies of microglia are needed that also incorporate $\beta$-catenin and GSK-3 $\beta$ genotypes and or signaling networks in order to understand pathogenic significance of microglia in BD.

\section{FUNCTIONAL BRAIN IMAGING: NEUROTRANSMITTERS AND MICROGLIA}

Advantages of in vivo imaging models

Investigation of therapeutic pathways and microglia related mechanisms for BD has been challenging because there are few animal models that fully recapitulate the disease. Most of the current information comes from postmortem studies. ${ }^{44,88,89}$ One limitation of postmortem tissue investigation is that the tissue is usually obtained after a person died or at the end stage of the disease. Despite the potential to understand BD noninvasively and therefore in a highly relevant milieu in human subjects, BD has received only limited attention in molecular imaging studies. Functional neuroimaging modalities such as positron emission tomography (PET), single-photon emission computed tomography and functional magnetic resonance imaging offer powerful, noninvasive methods to examine brain structure and neurochemical correlates involved in mood. Animal systems that combine cellular and molecular observations with imaging are being applied to the study of psychiatric illnesses. One potential caveat of in vivo brain imaging is its sensitivity in identifying biological mechanism at the protein and receptor level in human subjects in either the depressed or manic phase of the illness.

\section{Imaging the serotonin transporter in $\mathrm{BD}$}

In human subjects research, structural and functional studies are emerging in mood disorders, with the most consistent neuroimaging data related to alterations in serotonergic signaling in unipolar depression (MDD). ${ }^{32,36,44,45}$ However, translating observations in unipolar depression with findings in bipolar depression ${ }^{90}$ have not always been consistent. Studies with the 5-HTT ligand $\left[{ }^{123}\right.$ I]ADAM in MDD demonstrate decreased 5-HTT availability, whereas those with $\left[{ }^{11} \mathrm{C}\right](+) \mathrm{McN} 5652$ demonstrate increased 5 -HTT binding in mood disorders. ${ }^{44,91,92}$ The discrepancies in the 5 -HTT findings have been attributed to differences in the radiopharmaceuticals used, the mood state, age of the patients and imaging duration. ${ }^{4,93,94}$ Although bipolar patients comprised only a small portion of the study, bipolar patients and depressed patients with bipolar relatives showed increased, although not significant, 5-HT1a binding in the raphe and mesiotemporal cortex. An increase in 5-HTT was observed in the thalamus of bipolar patients and unipolar depressed patients with bipolar relatives. ${ }^{44,92}$

The 5-HTT radiopharmaceutical $\left[{ }^{11} \mathrm{C}\right]$-3-amino-4-(2-dimethyl amionomethyl-phenylsulfanyl)-benzonitrile, $\left[{ }^{11} \mathrm{C}\right] \mathrm{DASB}$ has enabled sensitive detection of alterations in serotonergic transmission. ${ }^{95,96}\left[{ }^{11} \mathrm{C}\right]$ DASB was found to be a more effective radioligand for the serotonin transporter owing to its fast kinetics, reversibility, higher selectivity, greater specific binding and higher reproducibility. ${ }^{96-98}$ In vivo evaluation of $5-\mathrm{HTT}$ with $\left[{ }^{11} \mathrm{C}\right] \mathrm{DASB}$ has been used by several groups in the setting of alcoholism, tryptophan depletion, occupancy studies of different SSRI medications and most recently in our lab in HIV-associated depression. ${ }^{98-101}$ Interesting studies in unipolar depression showed increased binding to 5-HTT and a return to normal $5-\mathrm{HTT}$ availability in recovered depressed patients in a euthymic mode. ${ }^{32,43,102-104}$ However, in bipolar-depressed patients, the data from several studies to date have not been so consistent. ${ }^{32,45,105}$ One study genotyped for bi- and triallelic 5-HTTLPR polymorphisms in bipolar-depressed patients demonstrated lower 5-HTT binding in $\mathrm{BD}$ and no difference in 5-HTTLP in $\mathrm{BD}$ compared with controls. ${ }^{45}$ However, imaging was done with a radiopharmaceutical that some believe has less specific binding than $\left[{ }^{11} \mathrm{C}\right]$ DASB. ${ }^{96,106}$ The other study used PET imaging with $\left[{ }^{11} \mathrm{C}\right] \mathrm{DASB}$ in $\mathrm{BD}$, unipolar depression and controls. Unipolar depression and $\mathrm{BD}$ were both associated with elevated 5-HTT binding in the insula, thalamus and striatum, but showed distinct abnormalities in the brainstem. $^{32}$ The BD finding could be explained by potential medication effects, the varied genetic background of the patients studied or conceivably because of underlying differences in the pattern of symptoms between MDD and BD. ${ }^{32}$ To address some of the confounding factors that have appeared in the neuroimaging literature, future studies are needed that focus on imaging families with $\mathrm{BD}$ or individuals with common genetic polymorphisms.

\section{Imaging studies that target microglia}

Molecular imaging methods to study activated microglia as a marker of neuroinflammation may lend insight into the pathogenesis of BD-related symptoms. Structural imaging studies report lower glial and neuronal cell volume and density in the dorsolateral prefrontal cortex and amygdala of patients with MDD $^{85,107}$ and the subgenual cortex in familial BD. ${ }^{108,109}$

TSPO is an $18-\mathrm{kDa}$, mitochondrial membrane protein that is involved in a wide variety of functions including induction of apoptosis, cholesterol transport and modulation of inflammatory responses. ${ }^{110}$ Known until recently as the peripheral benzodiazepine receptor (PBR), but expressed in the brain and the periphery, TSPO has been linked to in vivo monitoring of glial cell activation. $9,110,111$ Specifically, glial cells that are inactive have low expression of TSPO, whereas active cells have increased expression. ${ }^{12-114}$ As glia cells can be activated by a variety of brain insults, the measurement of TSPO binding is arguably a useful measurement of inflammation in injured or diseased brain regions. The TSPO ligand that has been used the most as a potential inflammatory marker in PET imaging is $\left[{ }^{11} \mathrm{C}\right]-R$ PK11195. ${ }^{115-118}$ However, $\left[{ }^{11} \mathrm{C}\right]-R$-PK11195 is characterized by high nonspecific binding, high plasma protein binding and low brain uptake. ${ }^{115}$ To address those limitations, our group and 


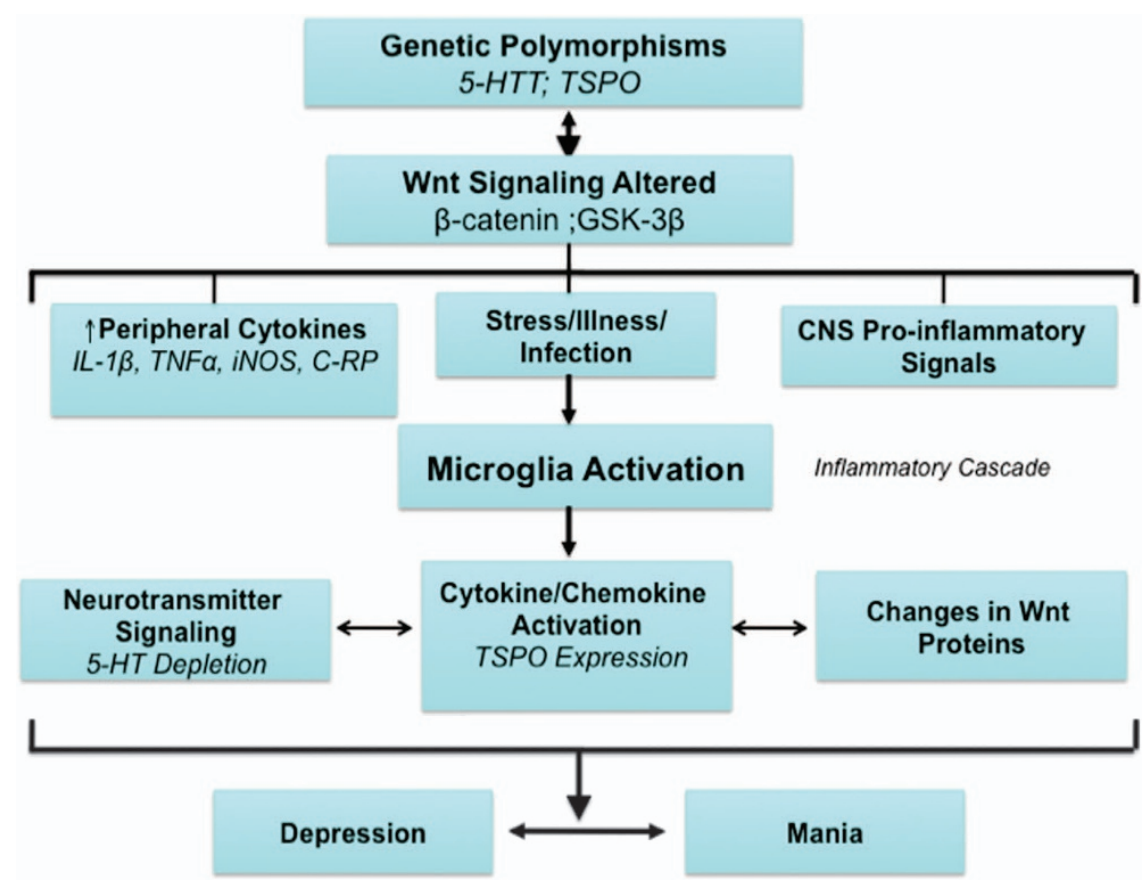

Figure 3. Microglia express TSPO and Beta-catenin that connect monoamine synthesis and the Wnt pathway. (5-HTT, serotonin transporter; CRP, C-reactive protein; 5-HT, serotonin; TSPO, translocator protein).

others used the PET ligand $\left[{ }^{11} \mathrm{C}\right] N, N$-diethyl-2-[2-(4-methoxyphenyl)-5,7-dimethyl-pyrazolo[1,5-a]pyrimidin-3-yl]-acetamide, $\quad\left[{ }^{11} \mathrm{C}\right]$ DPA-713, which appears to bind to the TSPO, as a plausible way to study microglial activation and implied neuroinflammation in vivo, ${ }^{119}$ with $\left[{ }^{11} \mathrm{C}\right] \mathrm{DPA}-713-\mathrm{PET}$ as a developing method by which to evaluate inflammation. ${ }^{120}$ We examined the cerebral uptake of $\left[{ }^{11} \mathrm{C}\right] \mathrm{DPA}-713$ in healthy human control subjects and found that $\left[{ }^{11} \mathrm{C}\right] \mathrm{DPA}-713$ had substantially greater delivery and increased specific binding compared with $\left[{ }^{11} \mathrm{C}\right]-R$-PK11195. ${ }^{120}$ Those results indicate that $\left[{ }^{11} \mathrm{C}\right] D P A-713$ is a promising TSPO ligand for investigating what is likely neuroinflammation with PET. Wholebody PET/computed tomography of $\left[{ }^{11} \mathrm{C}\right] \mathrm{DPA}-713$ shows an uptake pattern that is consistent with the biodistribution of TSPO and yields a dose burden that is comparable to that of other $\left[{ }^{11} \mathrm{C}\right]-$ labeled PET tracers. ${ }^{121}$ Our preliminary studies with $\left[{ }^{11} \mathrm{C}\right] \mathrm{DPA}-713$ show increased volume of distribution in the anterior and posterior cingulated gyrus and the ventral lateral thalamus. ${ }^{77}$

Other TSPO ligands are emerging as promising imaging agents for the practical quantification of microglia. $\left[{ }^{11} \mathrm{C}\right] \mathrm{PBR} 28$ binds to TSPO and has been used in PET imaging to assess potential microglial activation. . $22,123-125$ Other second-generation TSPO ligands evaluated in major psychiatric illnesses include $\left[{ }^{11} \mathrm{C}\right]$ vinpocetine, ${ }^{126}\left[{ }^{18} \mathrm{~F}\right]$-FEPPA, $\left[{ }^{11} \mathrm{C}\right] \mathrm{DAA} 1106,{ }^{127}\left[{ }^{18} \mathrm{~F}\right]-\mathrm{PBR} 06{ }^{128}$ and several other pharmacological probes. ${ }^{117}$ To date, many of the second-generation TSPO ligands have been used to study TSPO binding in Alzheimer's disorder, with no studies reported to date in mood or psychotic disorders. ${ }^{126,127,129}$

\section{FROM NEUROPHARMACOLOGY AND BRAIN IMAGING TO CLINICAL APPLICATION}

Factoring genetics into molecular imaging studies of BD

Despite the potential to understand microglia, noninvasively in human subjects, finding a homogenous group of patients with BD has been challenging because $\mathrm{BD}$ is a multi-factorial mental disorder with proposed heritability. There are susceptibility genes that may impact the severity and duration of illness episodes through interactions with the environment. Several studies estimate a lifetime incidence of BD of $60 \%$ in monozygotic twins, $7 \%$ in first-degree relatives and an overall heritability of $80 \% .6,61,130$ Although the results from linkage and association studies have not been easily comparable, there are regions in the genome consistently associated with BD that correlate with biological functions of mood and neuroplasticity and are expressed in the brain. ${ }^{131,132}$ In addition, stress from significant life events, impact of substance abuse, hormonal dysregulation and sleep deprivation are confounding factors known to contribute to the chronicity of the illness and factor into mood state. ${ }^{6,131}$ Newer imaging studies have attempted to factor aspects of heritability into clinical studies. ${ }^{133}$ Functional magnetic resonance imaging and PET studies have shown that depressionlike symptoms of fatigue and psychomotor slowing correlate with altered neuronal activity in the putamen, nucleus accumbens, amygdala and the substantia nigra. ${ }^{44,90,134}$ Interestingly, the 5-HTTLPR genotype was associated with a higher incidence of MDD during IFN- $\gamma$ treatment. ${ }^{135,136}$ Recent PET studies have also incorporated genetic polymorphisms with imaging techniques. ${ }^{133}$ Owen et al. ${ }^{123}$ describe genetic differences in TSPO genotypes underlying brain uptake patterns of TSPO-targeting radiotracers. Specifically, a TSPO Ala147Thr polymorphism predicts PBR28binding affinity in human platelets. There appears to be high, medium and low affinity-binding polymorphisms for all of the second-generation TSPO ligands that will have to be factored into any future imaging studies. ${ }^{123,124}$

Clinical correlates of glial and immune signaling

Pro-inflammatory cytokines in both the peripheral and signaled by microglia in the CNS appear to operate in parallel and are involved in clinically relevant aspects of $\mathrm{BD}$, including neuronal plasticity, neurotransmitter synthesis and neuroendocrine processes. ${ }^{12,15,137}$ There are several lines of clinical and pharmacological evidence that are consistent with microglia involvement in the inflammatory hypothesis of BD. They include:

(1) Patients with systemic inflammatory disorders such as coronary artery disease, multiple sclerosis, Crohn's disease, cancer, 
HIV and rheumatoid arthritis have a higher incidence of mood disorders compared with medically healthy individuals; ${ }^{137-139}$

(2) BD is associated with a greater prevalence of diabetes mellitus, thyroid disease, obesity and other neuroendocrine diseases associated with inflammation; ${ }^{140,141}$

(3) Increased production of pro-inflammatory cytokines IL-2, IL-2 receptor IL-6 $(P<0.01)$, TNF- $(P<0.05)$ and markers of inflammation, chemokines, C-reactive protein and adhesion molecules have been demonstrated in the blood and CSF in both the manic and depressive phases of BD compared with healthy subjects; ${ }_{i}^{25,45,12,26,142}$

(4) Acutely ill BD patients with systemic inflammation and nonhepatic tissue damage have a higher risk for early natural death, which is reduced with Li treatment; ${ }^{138}$

(5) Targeted therapies with anti-inflammatory agents such as eicosanoids, cyclooxygenase 2 inhibitors and antagonists to TNF- have been shown to ameliorate symptoms in MDD and BD patients. $^{143}$

Studies in patients on chronic IFN-a therapy have been some of the most compelling in identifying neuroanatomical targets for cytokine effects. ${ }^{12,144}$ Previously euthymic hepatitis $C$ and cancer patients undergoing chronic IFN- $\gamma$ treatment have been observed to exhibit hypomanic-type symptoms of hypervigilence, irritability and anxiety, as well as full-blown mania. ${ }^{12,145}$ Those studies suggest a particular vulnerability in the dorsal anterior cingulate cortex compared with non-IFN- $\gamma$ treated control subjects. ${ }^{146}$ Neuroimaging data demonstrate that BD as well as high anxiety, obsessive-compulsive traits and difficulty with conflict resolution have been associated with the dorsal anterior cingulate cortex. $^{93,147,148}$ Prospective studies further identified an occurrence of depression of $30-50 \%$ in cancer patients treated with IFN- $\gamma$ and chemotherapeutic agents. ${ }^{135,145,149}$ These clinical correlations combined with a translational research approach from lessons in pharmacology and neuroimaging will hopefully lead to more studies designed to understand the pathophysiology of BD.

\section{SUMMARY}

BD is a prevalent illness with significant disability and early mortality through suicide. The mechanisms through which both depression and BD develop are poorly understood. The monoamine hypothesis of mood disorders suggests that one of the biological bases of bipolar depression is a deficiency in serotonin. As glial cell activation (Figure 3 ) represents a potential common pathway for serotonin synthesis and neuronal plasticity, the available data strongly support translational, in vivo imaging of inflammation as an encouraging area of investigation for the proposed examination of the pathophysiology of BD. ${ }^{117,133}$ The relevance of these studies is emphasized by the prevalence of BD and the need to implement early diagnostic and improved treatment interventions in order to decrease the morbidity and mortality associated with the illness. Molecular imaging research on the pathophysiology of $\mathrm{BD}$ and mechanisms pertaining to inflammation, alterations in serotonergic transmission and neuroplasticity are sparse. So far, PET studies to evaluate transporter availability in BD have focused on monoamine systems, including serotonin (5-HT) and the serotonin transporter $(5-\mathrm{HTT})$, with both null and positive results depending on the demographics of the population studied. Important information will be acquired regarding the interactions of genetic factors and inflammatory mediators in bipolar patients, as well as the specific role of $5-\mathrm{HTT}$ in the regulation of cellular plasticity cascades in BD. With experimental limitations from animal models and postmortem tissue for BD, we believe that future brain imaging studies in combination with translational methods will addresses the unmet needs for a coherent and comprehensive clinical model of BD. There is also a need to identify relevant inflammatory targets for improved therapeutic interventions. A growing body of literature also supports an increased appreciation for the integrated role of microglia in mood disorders research. An understanding of glia and immune signaling will potentially enhance discovery in the brain and behavioral sciences and fuel research on the causes of mental disorders.

\section{CONFLICT OF INTEREST}

The authors declare no conflict of interest.

\section{ACKNOWLEDGMENTS}

This work was supported by the Johns Hopkins University Mosaic Initiative and US National Institute of Health 2T32MH015330-32 (to CCW).

\section{REFERENCES}

1 Kessler RC, Chiu WT, Demler O, Merikangas KR, Walters EE Prevalence, severity, and comorbidity of 12-month DSM-IV disorders in the National Comorbidity Survey Replication. Arch Gen Psychiatr 2005; 62: 617-627.

2 Bartels SJ, Forester B, Miles KM, Joyce T Mental health service use by elderly patients with bipolar disorder and unipolar major depression. Am J Geriatr Psychiatry 2000; 8 : 160-166.

3 Stensland MD, Schultz JF, Frytak JR Depression diagnoses following the identification of bipolar disorder: costly incongruent diagnoses. BMC Psychiatry 2010; 10: 39.

4 Begley CE, Annegers JF, Swann AC, Lewis C, Coan S, Schnapp WB et al. The lifetime cost of bipolar disorder in the US: an estimate for new cases in 1998. PharmacoEconomics 2001; 19(Pt 1): 483-495.

5 Association AP. Clinical Practice Guidelines 2005, http://www.psychiatry.org/ practice/clinical-practice-guidelines. Accessed August 2013.

6 Goodwin FK, Jamison KR Manic-Depressive Illness: Bipolar Disorders and Recurrent Depression. 2nd edn. Oxford Univeristy Press: Oxford, UK, 2007.

7 Schloesser RJ, Huang J, Klein PS, Manji HK Cellular plasticity cascades in the pathophysiology and treatment of bipolar disorder. Neuropsychopharmacology 2008; 33: 110-133.

8 Manji HK, Lenox RH The nature of bipolar disorder. J Clin Psychiatry 2000; 61 (Supp 13): 42-57.

9 Ekdahl CT, Kokaia Z, Lindvall O Brain inflammation and adult neurogenesis: the dual role of microglia. Neuroscience 2009; 158: 1021-1029.

10 Kapczinski F, Frey BN, Kauer-Sant'Anna M, Grassi-Oliveira R Brain-derived neurotrophic factor and neuroplasticity in bipolar disorder. Exp Rev Neurother 2008; 8: $1101-1113$.

11 Koo JW, Duman RS IL-1beta is an essential mediator of the antineurogenic and anhedonic effects of stress. Proc Natl Acad Sci USA 2008; 105: 751-756.

12 Miller $\mathrm{AH}$, Maletic $\mathrm{V}$, Raison $\mathrm{CL}$ Inflammation and its discontents: the role of cytokines in the pathophysiology of major depression. Biol Psychiatry 2009; 65: 732-741.

13 Blank T, Prinz M Microglia as modulators of cognition and neuropsychiatric disorders. Glia 2013; 61: 62-70.

14 Beumer W, Drexhage RC, De Wit H, Versnel MA, Drexhage HA, Cohen D Increased level of serum cytokines, chemokines and adipokines in patients with schizophrenia is associated with disease and metabolic syndrome. Psychoneuroendocrinology 2012; 37: 1901-1911.

15 Beumer W, Gibney SM, Drexhage RC, Pont-Lezica L, Doorduin J, Klein HC et al. The immune theory of psychiatric diseases: a key role for activated microglia and circulating monocytes. J Leuk Biol 2012; 92: 959-975.

16 Drexhage RC, Knijff EM, Padmos RC, Heul-Nieuwenhuijzen Lvd, Beumer W, Versnel MA et al. The mononuclear phagocyte system and its cytokine inflammatory networks in schizophrenia and bipolar disorder. Exp Rev Neurother 2010; 10: 59-76.

17 Geddes JR, Burgess S, Hawton K, Jamison K, Goodwin GM Long-term lithium therapy for bipolar disorder: systematic review and meta-analysis of randomized controlled trials. Am J Psychiatry 2004; 161: 217-222.

18 Schloesser RJ, Martinowich K, Manji HK Mood-stabilizing drugs: mechanisms of action. Trends Neurosci 2012; 35: 36-46.

19 Rapaport MH, Manji HK The effects of lithium on ex vivo cytokine production. Biol Psychiatry 2001; 50: 217-224

20 Kilander MB, Halleskog C, Schulte G Recombinant Wnts differentially activate beta-catenin-dependent and -independent signalling in mouse microglialike cells. Acta Physiol 2011; 203: 363-372.

21 Halleskog C, Schulte G WNT-3A and WNT-5A counteract lipopolysaccharideinduced pro-inflammatory changes in mouse primary microglia. $J$ Neurochem 2013; 125: 803-808. 
22 Zarate CA Jr., Singh J, Manji HK Cellular plasticity cascades: targets for the development of novel therapeutics for bipolar disorder. Biol Psychiatry 2006; 59 . 1006-1020.

23 Wichers $M C$, Maes $M$ The role of indoleamine 2,3-dioxygenase (IDO) in the pathophysiology of interferon-alpha-induced depression. J Psychiatry Neurosci 2004; 29: 11-17.

24 Miller CL, Llenos IC, Cwik M, Walkup J, Weis S Alterations in kynurenine precursor and product levels in schizophrenia and bipolar disorder. Neurochem Int 2008; 52: 1297-1303.

25 Myint AM, Kim YK, Verkerk R, Park SH, Scharpe S, Steinbusch HW et al. Tryptophan breakdown pathway in bipolar mania. J Affect Dis 2007; 102: 65-72.

26 Munkholm K, Vinberg M, Vedel Kessing L Cytokines in bipolar disorder: a systematic review and meta-analysis. J Affect Dis 2013; 144: 16-27.

27 Miller CL, Llenos IC, Dulay JR, Weis S Upregulation of the initiating step of the kynurenine pathway in postmortem anterior cingulate cortex from individuals with schizophrenia and bipolar disorder. Brain Res 2006; 1073-1074: 25-37.

28 Dean B The neurobiology of bipolar disorder: findings using human postmortem central nervous system tissue. Aust N Z J Psychiatry 2004; 38 : 135-140.

29 Collier DA, Stober G, Li T, Heils A, Catalano M, Di Bella D et al. A novel functional polymorphism within the promoter of the serotonin transporter gene: possible role in susceptibility to affective disorders. Mol Psychiatry 1996; 1: 453-460.

30 Bull SJ, Huezo-Diaz P, Binder EB, Cubells JF, Ranjith G, Maddock C et al. Functional polymorphisms in the interleukin- 6 and serotonin transporter genes, and depression and fatigue induced by interferon-alpha and ribavirin treatment. $\mathrm{Mol}$ Psychiatry 2009; 14: 1095-1104.

31 Felger JC, Lotrich FE. Inflammatory cytokines in depression: Neurobiologica mechanisms and therapeutic implications. Neuroscience 2013; 246: 199-229.

32 Cannon DM, Ichise M, Rollis D, Klaver JM, Gandhi SK, Charney DS et al. Elevated serotonin transporter binding in major depressive disorder assessed using positron emission tomography and [11C]DASB; comparison with bipolar disorder. Biol Psychiatry 2007; 62: 870-877.

33 Caspi A, Sugden K, Moffitt TE, Taylor A, Craig IW, Harrington $\mathrm{H}$ et al. Influence of life stress on depression: moderation by a polymorphism in the $5-\mathrm{HTT}$ gene. Science 2003; 301: 386-389.

34 Kendler KS, Kuhn JW, Vittum J, Prescott CA, Riley B. The interaction of stressful life events and a serotonin transporter polymorphism in the prediction of episodes of major depression: a replication. Arch Gen Psychiatry 2005; 62: 529-535.

35 Lesch KP, Balling U, Gross J, Strauss K, Wolozin BL, Murphy DL et al. Organization of the human serotonin transporter gene. J Neural Transm Gen Sect 1994; 95: 157-162.

36 Collier DA, Arranz MJ, Sham P, Battersby S, Vallada H, Gill P et al. The serotonin transporter is a potential susceptibility factor for bipolar affective disorder. Neuroreport 1996; 7: 1675-1679.

37 Rees M, Norton N, Jones I, McCandless F, Scourfield J, Holmans P et al. Association studies of bipolar disorder at the human serotonin transporter gene (hSERT; 5HTT). Mol Psychiatry 1997; 2: 398-402.

38 Heyes MP, Saito K, Crowley JS, Davis LE, Demitrack MA, Der M et al. Quinolinic acid and kynurenine pathway metabolism in inflammatory and noninflammatory neurological disease. Brain 1992; 115(Pt 5): 1249-1273.

39 Myint AM, Kim YK, Verkerk R, Scharpe S, Steinbusch H, Leonard B. Kynurenine pathway in major depression: evidence of impaired neuroprotection. $J$ Affect Dis 2007; 98: 143-151.

40 Beaulieu JM, Zhang X, Rodriguiz RM, Sotnikova TD, Cools MJ, Wetsel WC et al. Role of GSK3 beta in behavioral abnormalities induced by serotonin deficiency. Proc Natl Acad Sci USA 2008; 105: 1333-1338.

41 Steiner J, Walter M, Gos T, Guillemin GJ, Bernstein HG, Sarnyai Z et al. Severe depression is associated with increased microglial quinolinic acid in subregions of the anterior cingulate gyrus: evidence for an immune-modulated glutamatergic neurotransmission? J Neuroinflam 2011; 8: 94.

42 Sanacora G, Gueorguieva R, Epperson CN, Wu YT, Appel M, Rothman DL et al. Subtype-specific alterations of gamma-aminobutyric acid and glutamate in patients with major depression. Arch Gen Psychiatry 2004; 61 : 705-713.

43 Bhagwagar Z, Wylezinska M, Jezzard P, Evans J, Ashworth F, Sule A et al. Reduction in occipital cortex gamma-aminobutyric acid concentrations in medication-free recovered unipolar depressed and bipolar subjects. Biol Psychiatry 2007; 61: 806-812.

44 Strakowski SM, Adler CM, Holland SK, Mills NP, DelBello MP, Eliassen JC. Abnormal FMRI brain activation in euthymic bipolar disorder patients during a counting Stroop interference task. Am J Psychiatry 2005; 162: 1697-1705.

45 Oquendo MA, Hastings RS, Huang YY, Simpson N, Ogden RT, Hu XZ et al. Brain serotonin transporter binding in depressed patients with bipolar disorder using positron emission tomography. Arch Gen Psychiatry 2007; 64: 201-208.

46 Cerullo MA, Fleck DE, Eliassen JC, Smith MS, DelBello MP, Adler CM et al. A longitudinal functional connectivity analysis of the amygdala in bipolar I disorder across mood states. Bipolar Dis 2012; 14: 175-184.
47 Goldstein BI, Kemp DE, Soczynska JK, Mclntyre RS. Inflammation and the phenomenology, pathophysiology, comorbidity, and treatment of bipolar disorder: a systematic review of the literature. J Clin Psychiatry 2009; 70: 1078-1090.

48 Craddock N, Sklar P. Genetics of bipolar disorder. Lancet 2013; 381: 1654-1662.

49 Ichiyama T, Okada K, Lipton JM, Matsubara T, Hayashi T, Furukawa S. Sodium valproate inhibits production of TNF-alpha and IL- 6 and activation of NF-kappaB. Brain Res 2000; 857: 246-251.

50 Chen PS, Wang CC, Bortner CD, Peng GS, Wu X, Pang H et al. Valproic acid and other histone deacetylase inhibitors induce microglial apoptosis and attenuate lipopolysaccharide-induced dopaminergic neurotoxicity. Neuroscience 2007; 149 : 203-212.

51 Nahman S, Belmaker RH, Azab AN. Effects of lithium on lipopolysaccharide-induced inflammation in rat primary glia cells. Innate Immun 2012; 18 : 447-458.

52 Knijff EM, Breunis MN, Kupka RW, de Wit HJ, Ruwhof C, Akkerhuis GW et al. An imbalance in the production of IL-1 beta and IL- 6 by monocytes of bipolar patients: restoration by lithium treatment. Bipolar Dis 2007; 9: 743-753.

53 Boufidou F, Nikolaou C, Alevizos B, Liappas IA, Christodoulou GN. Cytokine production in bipolar affective disorder patients under lithium treatment. J Affect Dis 2004; 82: 309-313.

54 O'Brien WT, Harper AD, Jove F, Woodgett JR, Maretto S, Piccolo S et al. Glycogen synthase kinase-3beta haploinsufficiency mimics the behavioral and molecular effects of lithium. J Neurosci 2004; 24 : 6791-6798.

55 Chen PS, Peng GS, Li G, Yang S, Wu X, Wang CC et al. Valproate protects dopaminergic neurons in midbrain neuron/glia cultures by stimulating the release of neurotrophic factors from astrocytes. Mol Psychiatry 2006; 11 1116-1125.

56 Barrientos RM, Sprunger DB, Campeau S, Higgins EA, Watkins LR, Rudy JW et al. Brain-derived neurotrophic factor mRNA downregulation produced by social isolation is blocked by intrahippocampal interleukin-1 receptor antagonist. Neuroscience 2003; 121: 847-853.

57 Klein PS, Melton DA. A molecular mechanism for the effect of lithium on development. Proc Natl Acad Sci USA 1996; 93: 8455-8459.

58 Padmos RC, Hillegers MH, Knijff EM, Vonk R, Bouvy A, Staal FJ et al. A discriminating messenger RNA signature for bipolar disorder formed by an aberrant expression of inflammatory genes in monocytes. Arch Gen Psychiatry 2008; 65: 395-407.

59 Peineau S, Bradley C, Taghibiglou C, Doherty A, Bortolotto ZA, Wang YT et al. The role of GSK-3 in synaptic plasticity. Br J Pharmacol 2008; 153(Suppl 1): S428-S437.

60 Zandi PP, Belmonte PL, Willour VL, Goes FS, Badner JA, Simpson SG et al. Association study of Wnt signaling pathway genes in bipolar disorder. Arch Gen Psychiatry 2008; 65: 785-793.

61 Gould TD, Manji HK. The Wnt signaling pathway in bipolar disorder Neuroscientist 2002; 8: 497-511.

62 Beasley C, Cotter D, Everall I. An investigation of the Wnt-signalling pathway in the prefrontal cortex in schizophrenia, bipolar disorder and major depressive disorder. Schizophr Res 2002; 58: 63-67.

63 Prickaerts J, Moechars D, Cryns K, Lenaerts I, van Craenendonck H, Goris I et al. Transgenic mice overexpressing glycogen synthase kinase 3beta: a putative model of hyperactivity and mania. J Neurosci 2006; 26: 9022-9029.

64 Mao Y, Ge X, Frank CL, Madison JM, Koehler AN, Doud MK et al. Disrupted in schizophrenia 1 regulates neuronal progenitor proliferation via modulation of GSK3beta/beta-catenin signaling. Cell 2009; 136: 1017-1031.

65 Godbout JP, Johnson RW Age and neuroinflammation: a lifetime of psychoneuroimmune consequences. Immunol Allergy Clin North Am 2009; 29: 321-337.

66 Matigian N, Windus L, Smith H, Filippich C, Pantelis C, McGrath J et al. Expression profiling in monozygotic twins discordant for bipolar disorder reveals dysregulation of the WNT signalling pathway. Mol Psychiatry 2007; 12: 815-825.

67 Sklar P, Smoller JW, Fan J, Ferreira MA, Perlis RH, Chambert K et al. Wholegenome association study of bipolar disorder. Mol Psychiatry 2008; 13: 558-569.

68 Schulze TG, Buervenich S, Badner JA, Steele CJ, Detera-Wadleigh SD, Dick D et al. Loci on chromosomes $6 q$ and $6 p$ interact to increase susceptibility to bipola affective disorder in the national institute of mental health genetics initiative pedigrees. Biol Psychiatry 2004; 56: 18-23.

69 Raybould R, Green EK, MacGregor S, Gordon-Smith K, Heron J, Hyde S et al. Bipolar disorder and polymorphisms in the dysbindin gene (DTNBP1). Bio Psychiatry 2005; 57: 696-701.

70 Lewis CM, Levinson DF, Wise LH, DeLisi LE, Straub RE, Hovatta I et al. Genome scan meta-analysis of schizophrenia and bipolar disorder, part II: Schizophrenia. Am J Hum Genet 2003; 73: 34-48.

71 Straub RE, Jiang Y, MacLean CJ, Ma Y, Webb BT, Myakishev MV et al. Genetic variation in the $6 p 22.3$ gene DTNBP1, the human ortholog of the mouse dysbindin gene, is associated with schizophrenia. Am J Hum Genet 2002; 71 337-348. 
72 Berger J, Moller DE. The mechanisms of action of PPARs. Ann Rev Med 2002; 53: 409-435.

73 Braissant O, Foufelle F, Scotto C, Dauca M, Wahli W. Differential expression of peroxisome proliferator-activated receptors (PPARs): tissue distribution of PPARalpha, -beta, and -gamma in the adult rat. Endocrinology 1996; 137: 354-366.

74 Iwashita A, Muramatsu Y, Yamazaki T, Muramoto M, Kita Y, Yamazaki S et al. Neuroprotective efficacy of the peroxisome proliferator-activated receptor deltaselective agonists in vitro and in vivo. J Pharmacol Exp Ther 2007; 320: 1087-1096.

75 Goes FS, Sanders LL, Potash JB The genetics of psychotic bipolar disorder. Curr Psychiatry Rep 2008; 10 : 178-189.

76 Rajkowska G, Miguel-Hidalgo JJ. Gliogenesis and glial pathology in depression. CNS Neurol Disord Drug Targets 2007; 6: 219-233.

77 Watkins CC, Endres CJ, Rosenberg PB, Venkadatrii A, Coughlin J, Kassiou M et al. In Vivo PET Imaging of Glial Activation in Normal Aging Annual Meeting of the Society for Neuroscience. New Orleans, LA, 2012.

78 Tynan RJ, Weidenhofer J, Hinwood M, Cairns MJ, Day TA, Walker FR. A comparative examination of the anti-inflammatory effects of SSRI and SNRI antidepressants on LPS stimulated microglia. Brain Behav Immunity 2012; 26: 469-479.

79 Hashioka S, Klegeris A, Monji A, Kato T, Sawada M, McGeer PL et al. Antidepressants inhibit interferon-gamma-induced microglial production of IL-6 and nitric oxide. Exp Neurol 2007; 206 : 33-42.

80 Couch Y, Anthony DC, Dolgov O, Revischin A, Festoff B, Santos Al et al. Microglial activation, increased TNF and SERT expression in the prefrontal cortex define stress-altered behaviour in mice susceptible to anhedonia. Brain Behav Immunity 2013; 29: 136-146.

81 Horikawa H, Kato TA, Mizoguchi Y, Monji A, Seki Y, Ohkuri T et al. Inhibitory effects of SSRIs on IFN-gamma induced microglial activation through the regulation of intracellular calcium. Prog Neuropsychopharmacology Biol Psychiatry 2010; 34: 1306-1316.

82 Rajkowska G. Postmortem studies in mood disorders indicate altered numbers of neurons and glial cells. Biol Pychiatry 2000; 48: 766-777

83 Rajkowska G, Halaris A, Selemon LD. Reductions in neuronal and glial density characterize the dorsolateral prefrontal cortex in bipolar disorder. Biol Psychiatry 2001; 49: 741-752.

84 Cotter DR, Pariante CM, Everall IP. Glial cell abnormalities in major psychiatric disorders: the evidence and implications. Brain Res Bull 2001; 55: 585-595.

85 Keener MT, Phillips ML. Neuroimaging in bipolar disorder: a critical review of current findings. Curr Psychiatry Rep 2007; 9: 512-520.

86 Sani G, Napoletano F, Forte AM, Kotzalidis GD, Panaccione I, Porfiri GM et al. The wnt pathway in mood disorders. Curr Neuropharmacol 2013; $10: 239-253$.

87 Halleskog C, Schulte G. Pertussis toxin-sensitive heterotrimeric G(alphai/o) proteins mediate WNT/beta-catenin and WNT/ERK1/2 signaling in mouse primary microglia stimulated with purified WNT-3A. Cell Signal 2013; 25: 822-828.

88 Gallinat J, Bauer M, Heinz A. Genes and neuroimaging: advances in psychiatric research. Neurodegener Dis 2008; 5 277-285.

89 Laruelle M, Slifstein M, Huang Y. Positron emission tomography: imaging and quantification of neurotransporter availability. Methods 2002; 27: 287-299.

90 DelBello MP, Zimmerman ME, Mills NP, Getz GE, Strakowski SM. Magnetic resonance imaging analysis of amygdala and other subcortical brain regions in adolescents with bipolar disorder. Bipolar Dis 2004; 6: 43-52.

91 Drevets WC, Price JL, Furey ML. Brain structural and functional abnormalities in mood disorders: implications for neurocircuitry models of depression. Brain Struct Funct 2008; 213: 93-118.

92 Ichimiya T, Suhara T, Sudo Y, Okubo Y, Nakayama K, Nankai M et al. Serotonin transporter binding in patients with mood disorders: a PET study with $[11 \mathrm{C}](+)$ McN5652. Biol Psychiatry 2002; 51 : 715-722.

93 Savitz J, Drevets WC. Bipolar and major depressive disorder: neuroimaging the developmental-degenerative divide. Neurosci Biobehav Rev 2009; 33: 699-771.

94 Smith GS, Kahn A, Sacher J, Rusjan P, van Eimeren T, Flint A et al. Serotonin transporter occupancy and the functional neuroanatomic effects of citalopram in geriatric depression. Am J Geriatr Psychiatry 2011; 19: 1016-1025.

95 Frankle WG, Slifstein M, Gunn RN, Huang Y, Hwang DR, Darr EA et al. Estimation of serotonin transporter parameters with 11C-DASB in healthy humans: reproducibility and comparison of methods. J Nucl Med 2006; 47 : 815-826.

96 Ginovart N, Wilson AA, Meyer JH, Hussey D, Houle S. Positron emission tomography quantification of $[(11) C]$-DASB binding to the human serotonin transporter: modeling strategies. J Cereb Blood Flow Metab 2001; 21: 1342-1353.

97 Ichise M, Liow JS, Lu JQ, Takano A, Model K, Toyama H et al. Linearized reference tissue parametric imaging methods: application to [11C]DASB positron emission tomography studies of the serotonin transporter in human brain. J Cereb Blood Flow Metab 2003; 23: 1096-1112.

98 Brown AK, George DT, Fujita M, Liow JS, Ichise M, Hibbeln J et al. PET [11C]DASB imaging of serotonin transporters in patients with alcoholism. Alcohol Clin Exp Res 2007; 31: 28-32.
99 Praschak-Rieder N, Wilson AA, Hussey D, Carella A, Wei C, Ginovart N et al. Effects of tryptophan depletion on the serotonin transporter in healthy humans. Biol Psychiatry 2005; 58: 825-830.

100 Hammoud DA, Endres CJ, Hammond E, Uzuner O, Brown A, Nath A et al. Imaging serotonergic transmission with [11C]DASB-PET in depressed and non-depressed patients infected with HIV. Neurolmage 2010; 49: 2588-2595.

101 Parsey RV, Kent JM, Oquendo MA, Richards MC, Pratap M, Cooper TB et al. Acute occupancy of brain serotonin transporter by sertraline as measured by [11C] DASB and positron emission tomography. Biol Psychiatry 2006; 59: 821-828.

102 Reimold M, Batra A, Knobel A, Smolka MN, Zimmer A, Mann K et al. Anxiety is associated with reduced central serotonin transporter availability in unmedicated patients with unipolar major depression: a [11C]DASB PET study. Mol Psychiatry 2008; 13: 606-613, 557.

103 Meyer JH. Imaging the serotonin transporter during major depressive disorder and antidepressant treatment. J Psychiatry Neurosci 2007; 32: 86-102.

104 Meyer JH, Houle S, Sagrati S, Carella A, Hussey DF, Ginovart N et al. Brain serotonin transporter binding potential measured with carbon 11-labeled DASB positron emission tomography: effects of major depressive episodes and severity of dysfunctional attitudes. Arch Gen Psychiatry 2004; 61: 1271-1279.

105 Cannon TD, Keller MC. Endophenotypes in the genetic analyses of mental disorders. Ann Rev Clin Psychol 2006; 2: 267-290.

106 Wilson AA, Ginovart N, Hussey D, Meyer J, Houle S. In vitro and in vivo characterisation of [11C]-DASB: a probe for in vivo measurements of the serotonin transporter by positron emission tomography. Nucl Med Biol 2002; 29: 509-515.

107 Bowley MP, Drevets WC, Ongur D, Price JL. Low glial numbers in the amygdala in major depressive disorder. Biol Psychiatry 2002; 52: 404-412.

108 Ongur D, Drevets WC, Price JL. Glial reduction in the subgenual prefrontal cortex in mood disorders. Proc Natl Acad Sci USA 1998; 95: 13290-13295.

109 Drevets WC, Ongur D, Price JL. Neuroimaging abnormalities in the subgenual prefrontal cortex: implications for the pathophysiology of familial mood disorders. Mol Psychiatry 1998; 3: 220-226, 190-1.

110 Papadopoulos V, Baraldi M, Guilarte TR, Knudsen TB, Lacapere JJ, Lindemann P et al. Translocator protein $(18 \mathrm{kDa})$ : new nomenclature for the peripheral-type benzodiazepine receptor based on its structure and molecular function. Trends Pharmacol Sci 2006; 27: 402-409.

111 Innis RB, Cunningham VJ, Delforge J, Fujita M, Gjedde A, Gunn RN et al. Consensus nomenclature for in vivo imaging of reversibly binding radioligands. J Cereb Blood Flow Metab 2007; 27: 1533-1539.

112 Banati RB. Brain plasticity and microglia: is transsynaptic glial activation in the thalamus after limb denervation linked to cortical plasticity and central sensitisation? J Physiol 2002; 96: 289-299.

113 Banati RB, Myers R, Kreutzberg GW. PK ('peripheral benzodiazepine')—binding sites in the CNS indicate early and discrete brain lesions: microautoradiographic detection of [3 H]PK11195 binding to activated microglia. J Neurocytol 1997; 26: 77-82.

114 Myers R, Manjil LG, Cullen BM, Price GW, Frackowiak RS, Cremer JE. Macrophage and astrocyte populations in relation to [3 H]PK 11195 binding in rat cerebral cortex following a local ischaemic lesion. J Cereb Blood Flow Metab 1991; 11: 314-322.

115 Cagnin A, Kassiou M, Meikle SR, Banati RB. Positron emission tomography imaging of neuroinflammation. Neurotherapeutics 2007; 4: 443-452.

116 Turkheimer FE, Edison P, Pavese N, Roncaroli F, Anderson AN, Hammers A et al. Reference and target region modeling of [11C]-(R)-PK11195 brain studies. J NuCl Med 2007; 48: 158-167.

117 Venneti S, Lopresti BJ, Wiley CA. Molecular imaging of microglia/macrophages in the brain. Glia 2013; 61: 10-23.

118 Hammoud DA, Endres CJ, Chander AR, Guilarte TR, Wong DF, Sacktor NC et al. Imaging glial cell activation with [11C]-R-PK11195 in patients with AIDS. J Neurovirol 2005; 11: 346-355.

119 Boutin H, Chauveau F, Thominiaux C, Gregoire MC, James ML, Trebossen R et al. 11C-DPA-713: a novel peripheral benzodiazepine receptor PET ligand for in vivo imaging of neuroinflammation. J Nucl Med 2007; 48: 573-581.

120 Endres CJ, Pomper MG, James M, Uzuner O, Hammoud DA, Watkins CC et al. Initial Evaluation of 11C-DPA-713, a Novel TSPO PET Ligand, in Humans. J Nucl Med 2009; 50: 1276-1282.

121 Endres CJ, Coughlin JM, Gage KL, Watkins CC, Kassiou M, Pomper MG. Radiation dosimetry and biodistribution of the TSPO ligand 11C-DPA-713 in humans. J NuCl Med 2012; 53: 330-335.

122 Kreisl WC, Fujita M, Fujimura Y, Kimura N, Jenko KJ, Kannan P et al. Comparison of [(11)C]-(R)-PK 11195 and [(11)C]PBR28, two radioligands for translocator protein $(18 \mathrm{kDa})$ in human and monkey: Implications for positron emission tomographic imaging of this inflammation biomarker. Neurolmage 2010; 49: 2924-2932.

123 Owen DR, Gunn RN, Rabiner EA, Bennacef I, Fujita M, Kreisl WC et al. Mixedaffinity binding in humans with 18-kDa translocator protein ligands. J Nucl Med 2011; 52: 24-32. 
124 Owen DR, Yeo AJ, Gunn RN, Song K, Wadsworth G, Lewis A et al. An 18-kDa translocator protein (TSPO) polymorphism explains differences in binding affinity of the PET radioligand PBR28. J Cereb Blood Flow Metab 2012; 32: 1-5.

125 Kreisl WC, Jenko KJ, Hines CS, Lyoo CH, Corona W, Morse CL et al. A genetic polymorphism for translocator protein $18 \mathrm{kDa}$ affects both in vitro and in vivo radioligand binding in human brain to this putative biomarker of neuroinflammation. J Cereb Blood Flow Metab 2013; 33: 53-58.

126 Gulyas B, Toth M, Vas A, Shchukin E, Kostulas K, Hillert J et al. Visualising neuroinflammation in post-stroke patients: a comparative PET study with the TSPO molecular imaging biomarkers [11C]PK11195 and [11C]vinpocetine. Curr Radiopharm 2011; 5: 19-28.

127 Yasuno F, Kosaka J, Ota M, Higuchi M, Ito H, Fujimura $Y$ et al. Increased binding of peripheral benzodiazepine receptor in mild cognitive impairment-dementia converters measured by positron emission tomography with [(1)(1)C]DAA1106. Psychiatry Res 2012; 203: 67-74.

128 Fujimura Y, Zoghbi SS, Simeon FG, Taku A, Pike VW, Innis RB et al. Quantification of translocator protein $(18 \mathrm{kDa})$ in the human brain with PET and a nove radioligand, (18)F-PBR06. Journal of nuclear medicine: official publication. Soc Nucl Med 2009; 50: 1047-1053.

129 Kreisl WC, Lyoo CH, McGwier M, Snow J, Jenko KJ, Kimura $\mathrm{N}$ et al. In vivo radioligand binding to translocator protein correlates with severity of Alzheimer's disease. Brain 2013; 136(Pt 7): 2228-2238.

130 McGuffin P, Rijsdijk F, Andrew M, Sham P, Katz R, Cardno A. The heritability of bipolar affective disorder and the genetic relationship to unipolar depression. Arch Gen Psychiatry 2003; 60: 497-502.

131 Serretti A, Mandelli L. The genetics of bipolar disorder: genome 'hot regions,' genes, new potential candidates and future directions. Mol Psychiatry 2008; 13 : 742-771.

132 Wong ML, Dong C, Maestre-Mesa J, Licinio J. Polymorphisms in inflammationrelated genes are associated with susceptibility to major depression and antidepressant response. Mol Psychiatry 2008; 13: 800-812.

133 Savitz J, Frank MB, Victor T, Bebak M, Marino JH, Bellgowan PS et al. Inflammation and neurological disease-related genes are differentially expressed in depressed patients with mood disorders and correlate with morphometric and functional imaging abnormalities. Brain Behav Immunity 2012; 31: 161-171.

134 Brydon L, Harrison NA, Walker C, Steptoe A, Critchley HD. Peripheral inflammation is associated with altered substantia nigra activity and psychomotor slowing in humans. Biol Psychiatry 2008; 63: 1022-1029.

135 Lotrich FE, Rabinovitz M, Gironda P, Pollock BG. Depression following pegylated interferon-alpha: characteristics and vulnerability. J Psychosom Res 2007; 63 131-135.

136 Brietzke E, Kapczinski F. TNF-alpha as a molecular target in bipolar disorder. Prog Neuropsychopharmacol Biol Psychiatry 2008; 32: 1355-1361.
137 Dantzer R, O'Connor JC, Freund GG, Johnson RW, Kelley KW. From inflammation to sickness and depression: when the immune system subjugates the brain. Nat Rev Neurosci 2008; 9: 46-56.

138 Tsai SY, Lee CH, Kuo CJ, Chen CC. A retrospective analysis of risk and protective factors for natural death in bipolar disorder. J Clin Psychiatry 2005; 66 1586-1591.

139 Otte C, McCaffery J, Ali S, Whooley MA. Association of a serotonin transporter polymorphism (5-HTTLPR) with depression, perceived stress, and norepinephrine in patients with coronary disease: the Heart and Soul Study. Am J Psychiatry 2007; 164: 1379-1384.

140 McIntyre RS, Rasgon NL, Kemp DE, Nguyen HT, Law CW, Taylor VH et al. Metabolic syndrome and major depressive disorder: co-occurrence and pathophysiologic overlap. Curr Diabetes Rep 2009; 9: 51-59.

141 Ridker PM. Inflammatory biomarkers and risks of myocardial infarction, stroke diabetes, and total mortality: implications for longevity. Nutr Rev 2007; 65(Pt 2): S253-S259.

142 Dickerson F, Stallings C, Origoni A, Boronow J, Yolken R. Elevated serum levels of C-reactive protein are associated with mania symptoms in outpatients with bipolar disorder. Prog Neuropsychopharmacol Biol Psychiatry 2007; 31: 952-955.

143 Montgomery $\mathrm{P}$, Richardson AJ. Omega-3 fatty acids for bipolar disorder. Cochrane Database Syst Rev 2008: CD005169.

144 Zhu CB, Blakely RD, Hewlett WA. The proinflammatory cytokines interleukin1 beta and tumor necrosis factor-alpha activate serotonin transporters. Neu ropsychopharmacology 2006; 31: 2121-2131.

145 Capuron L, Ravaud A, Neveu PJ, Miller AH, Maes M, Dantzer R. Association between decreased serum tryptophan concentrations and depressive symptoms in cancer patients undergoing cytokine therapy. Mol Psychiatry 2002; 7 : 468-473.

146 Capuron L, Pagnoni G, Demetrashvili M, Woolwine BJ, Nemeroff CB, Berns GS et al. Anterior cingulate activation and error processing during interferon-alpha treatment. Biol Psychiatry 2005; 58: 190-196.

147 Carter CS, Braver TS, Barch DM, Botvinick MM, Noll D, Cohen JD. Anterio cingulate cortex, error detection, and the online monitoring of performance. Science 1998; 280: 747-749.

148 Slavich GM, Way BM, Eisenberger NI, Taylor SE. Neural sensitivity to social rejection is associated with inflammatory responses to social stress. Proc Natl Acad Sci USA 2010; 107: 14817-14822.

149 Capuron L, Miller AH. Cytokines and psychopathology: lessons from interferon-alpha. Biol Psychiatry 2004; 56: 819-824.

(i) $\$$ This work is licensed under a Creative Commons AttributionNonCommercial-NoDerivs 3.0 Unported License. To view a copy of this license, visit http://creativecommons.org/licenses/by-nc-nd/3.0/ 